między zawodami archiwisty i brokera informacji będą się - w wielu płaszczyznach - zacierać. Wciąż jednak wiele pytań pozostaje otwartych.

Bartosz Drzewiecki

(Uniwersytet Pedagogiczny w Krakowie)

\title{
Panel Archiwistyka i ZarząDZAnie doKumentaCjA PODCZAS XXIII OgólNOPOLSKIEgo ZJAZDU Historyków STUdentów w Toruniu
}

WW dniach od 21 do 25 IV 2015 r. mury toruńskiego Collegium Humanisticum Uniwersytetu Mikołaja Kopernika gościły studentów i doktorantów nauk historycznych podczas XXIII Ogólnopolskiego Zjazdu Historyków Studentów. Organizatorem wydarzenia prócz studentów i doktorantów tworzących komitet organizacyjny były Wydział Nauk Historycznych UMK oraz Instytut Historii i Archiwistyki UMK. Należy dodać, że jest to największa i najbardziej prestiżowa konferencja historyczna dla młodych badaczy. Hasłem tegorocznego zjazdu stały się słowa: „W drodze ku przyszłości”. Wśród referentów znaleźli się historycy, historycy sztuki, archiwiści, wojskoznawcy oraz osoby zajmujące się naukami pomocniczymi historii. Prócz wystąpień z referatami uczestnicy mogli podczas zjazdu wziąć udział w wydarzeniach towarzyszących: debatach pt. „Spory o historię” oraz „Ku przyszłości mediów historycznych”. Ponadto zorganizowano dwa wykłady otwarte, które przygotowali pracownicy IHiA UMK. Pierwszy wygłosił prof. Jarosław Dumanowski, który w przystępny i ciekawy sposób opowiedział o pierniku nazwanym toruńskim, który jest nie tylko smakiem historii, ale i symbolem miasta. W wystąpieniu skupił się na przedstawieniu ciekawych przepisów i receptur na pierniki. Drugi wykład został wygłoszony przez prof. Tomasza 
Kempę i dotyczył zapomnianego Samozwańca, Jana Faustyna Łuby i stosunków polsko-rosyjskich w pierwszej połowie XVII w.

Przedmiotem sprawozdania jest panel „Archiwistyka i zarządzanie dokumentacją", który odbył się drugiego dnia konferencji, 25 IV 2015 r. W tym miejscu należy podkreślić, iż toruńska archiwistyka może poszczycić się najdłuższą tradycją kształcenia archiwistów w Polsce. Z tego też względu podczas tak ważnego zjazdu nie mogło zabraknąć wystąpień związanych z tematyką archiwalną.

W obradach wzięli udział referenci reprezentujący następujące ośrodki naukowe: UMK, Uniwersytet im. Adama Mickiewicza w Poznaniu oraz Uniwersytet Pedagogiczny im. Komisji Edukacji Narodowej w Krakowie. Wystąpienia zostały podzielone na trzy części. Moderatorem pierwszych dwóch była dr Agnieszka Rosa, natomiast część ostatnią prowadził zastępca dyrektora IHiA prof. Krzysztof Kopiński. Prócz referentów, gości i studentów archiwistyki w obradach uczestniczyli prodziekan WH UMK prof. Waldemar Chorążyczewski i kierownik Zakładu Archiwistyki UMK prof. Wiesława Kwiatkowska. Zakład Zarządzania Dokumentacją i Informacji Archiwalnej UMK reprezentowała dr Marlena Jabłońska.

W trakcie panelu swe referaty wygłosiło dziesięć osób, choć plan zakładał, iż wystąpień będzie dwanaście. $Z$ nieznanych przyczyn dwóch referentów nie pojawiło się w trakcie obrad. Wystąpienia zostały podzielone na trzy części.

Obrady otworzył przewodniczący komitetu organizacyjnego zjazdu Mateusz Zmudziński (UMK), który wygłosił referat Uktad akt w parafii pw. Podwyższenia Krzyża Świętego w Górznie w XIX w. Autor omówił układ, jaki został nadany registraturze tej parafii przez proboszcza górznowskiego. Ukazał sposób funkcjonowania i dokumentowania życia parafii. Ponadto przedstawił, w jaki sposób archiwizowano akta. Podczas dyskusji zwrócono uwagę, iż celem pełnego zrozumienia nadanego układu należy odszukać egodokumenty proboszcza, które ukażą sposób myślenia i działania tejże osoby.

Kolejne wystąpienie pozostawało w tematyce archiwów kościelnych, gdyż Hanna Mollin (UMK) omówiła Obraz życia parafii pw. Świętego Jana Chrzciciela $w$ Świętego Jana Ewangelisty $w$ Świerczynkach w świetle ogtoszeń parafialnych z lat 1946-1980. Autorka na początku wystąpienia zaznaczyła, iż pracowała na oryginalnych rękopisach prowadzonych w formie zeszytowej przez proboszczów. Wskazała na różnice, jakie można zaobserwować w treści ogłoszeń po zmianie proboszczów, m.in. inny charakter pisma, styl wypowiedzi czy też rodzaj przekazywanych wiadomości. W referacie zostały przedstawio- 
ne najciekawsze elementy wynikające z treści ogłoszeń parafialnych. Jednym z nich było nauczanie moralne kapłanów, którzy nakazywali swym parafianom odbywanie sakramentu pokuty. Proboszczowie ponadto zwracali uwagę wiernym na imiona nadawane na chrzcie świętym, pragnęli oni, aby nowo narodzone dzieci nosiły imiona świętych.

$\mathrm{Z}$ nieznanych przyczyn referatu nie wygłosiła Kamila Siuda. Jej wystąpienie miało poruszać kwestię izby regionalnej jako placówki archiwalnej.

Ostatnim referentem pierwszej części panelu był Piotr Józefiak (UAM), który zajął się tematyką dokumentacji masowej. Tytuł wystąpienia brzmiał Problematyka archiwizacji kopert dowodowych na przyktadzie dokumentacji przechowywanej w Archiwum Urzędu Stanu Cywilnego w Krzywiniu. Autor zajął się dokumentacją, jaka jest gromadzona przez urzędy miast i gmin na potrzeby wydania dowodu osobistego. W trakcie wystąpienia przedstawił rys historyczny dowodu osobistego w Polsce oraz ukazał najważniejsze akty prawne, które regulowały sprawy dotyczące dowodów osobistych. Najwięcej uwagi poświęcił ukazaniu zmian, jakie zachodziły w przepisach dotyczących okresów przechowywania tej dokumentacji. Obecnie część akt dotycząca najstarszych dowodów osobistych jest uznawana za materiały archiwalne, co wiąże się z nadaniem odpowiedniego układu wewnętrznego kopert. Autor przedstawił, jakich wiadomości o obywatelu możemy dowiedzieć się z kopert dowodowych. Cenny głos w dyskusji zgłosił prodziekan Chorążyczewski, który zwrócił uwagę na zagadnienie ochrony danych osobowych osób zmarłych oraz wskazywał, iż należałoby sprawdzić, jakimi aspektami kierowali się archiwiści, podejmując decyzję o nadaniu tym materiałom kwalifikatora A.

Druga część obrad rozpoczęła się referatem Sonii Waleszczuk (UMK), która zajęła się problematyką archiwizacji internetu w polskim prawie. W tytule wystąpienia znalazło się stwierdzenie, że zagadnienie to należy traktować jako wyzwanie stojące przed archiwistami. Należy zaznaczyć, iż prelegentka przedstawiła wszelkie uwarunkowania prawne dotyczące informatyzacji oraz spraw związanych z archiwizacją dokumentacji utrwalonej w sieci.

Kolejne wystąpienie dotyczyło istoty procesu digitalizacji w polskich archiwach państwowych na przykładzie Narodowego Archiwum Cyfrowego. Temat ten przedstawiła Kamila Biernat (UMK, NAC), która prócz wyjaśnienia podstawowych terminów związanych z procesem digitalizacji wskazała na złożoność tego procesu w archiwach. W referacie omówione zostały wszystkie etapy digitalizacji - od wyboru dokumentu, który ma być poddany procesowi, aż do zamieszczenia go w Internecie. 
Następnie Anna Południak (UMK) zajęła się budowaniem wizerunku archiwum jako ważnego elementu jego działalności. Referat omawiał wszelkie działania popularyzatorskie i edukacyjne archiwów. Głos w dyskusji zabrał P. Józefiak, który na prośbę moderatora panelu, A. Rosy, omówił organizowane przez Archiwum Państwowe w Poznaniu „Popołudnia z dokumentem”, których głównym zadaniem jest popularyzowanie zasobu wśród środowiska lokalnego.

Ostatnim referentem drugiej części był Piotr Bewicz (UMK), który przedstawił referat pt. Kilka uwag o tym, czym stato się archiwum zaczynając od Jacquesa Derridy, ale nie pomijając Michela Foucaulta. Autor skupił się na tym, czym dla obu filozofów stało się archiwum oraz jak przedstawiali je w swoich dziełach. Ponadto w dyskusji poruszono kwestię upamiętnienia m.in. osób skazanych na karę śmierci.

Ostatnią, trzecią część panelu rozpoczęło wystąpienie Wioletty Smosnej (UP-KEN), które dotyczyło historii lokalnej zapisanej w sieci na przykładzie Bronowickiego Archiwum Społecznego. Prelegentka omówiła projekt realizowany przez Towarzystwo Przyjaciół Bronowic, którego celem było zgromadzenie wiedzy na temat historii życia codziennego Bronowic Małych. Autorka zaprezentowała stronę internetową projektu, na której zamieszczono wspomnienia najstarszych mieszkańców Bronowic Małych i archiwalia w postaci dokumentów i fotografii ofiarowanych przez mieszkańców. Ponadto wskazywała na to, że ciekawym uzupełnieniem wypowiedzi mieszkańców jest mapa budynków i miejsc, o których wspominali najstarsi mieszkańcy miejscowości.

Kolejny referat wygłosiła Magdalena Wiśniewska (UMK). Temat jej wystąpienia brzmiał Archiwa spoteczne w Polsce - krótka przesztość, świetlana przysztość?. W wystąpieniu autorka przedstawiła zjawisko archiwów społecznych w Polsce oraz ich historię. Omówiła, co może czekać archiwa społeczne w niedalekiej przyszłości. W dyskusji, która wywiązała się po tym wystąpieniu, uczestnicy panelu poruszali kwestię miejsc i ich lokalizację, w których powoływane są do życia archiwa społeczne. Dyskutanci doszli do wniosku, że stosunkowo niewiele archiwów społecznych występuje w województwach wschodnich oraz na Dolnym Śląsku. Wskazano, iż, mała obecność archiwów społecznych na terenie tzw. Ziem Odzyskanych może wynikać z braku związków miejscowej ludności, często zamieszkującej te ziemie w wyniku przesiedleń po II wojnie światowej, z dziedzictwem tych ziem.

Następnie głos zabrała Monika Cołbecka (UMK), która przedstawiła referat pt. Model badania systemu informacji archiwalnej. Autorka omówiła ba- 
danie systemu za pomocą metody matematycznej, reprezentacyjnej i eksperymentu. Autorka swoje badania przeprowadziła na podstawie zespołów przechowywanych w Archiwum Państwowym w Toruniu. Wskazała, że dość precyzyjnie można ocenić przydatność i efektywność pomocy archiwalnych.

Ostatnim referentem panelu miał być Mateusz Superczyński (UMK), który niestety nie pojawił się na obradach. Temat jego wystąpienia brzmiał: Socjotopografia podtoruńskiej osady Mokre w świetle nieznanych źródet archiwalnych $z$ XVI-XVIII $w$.

Należy podkreślić, że podczas zjazdu w innych panelach zostały wygłoszone referaty dotyczące lub nawiązujące do archiwistyki i nauk pomocniczych historii.

Podczas sejmiku studentów i doktorantów w dniu 25 IV 2015 r. organizatorem kolejnego, XXIV Ogólnopolskiego Zjazdu Historyków Studentów wybrany został Uniwersytet Jagielloński.

Piotr Józefiak

(Uniwersytet im. Adama Mickiewicza w Poznaniu)

\section{Warszawski Piknik Archiwalny}

http://dx.doi.org/10.12775/AKZ.2015.016

( zósty Warszawski Piknik Archiwalny odbył się 13 VI 2015 r. Przechylił S) szalę i przyjął kierunek ku organizacji kolejnych, zmierzających ku pierwszej dziesiątce imprez piknikowych. Każdy rok daje nam nowe doświadczenia, refleksje, małe zwycięstwa i małe porażki. Umacnia nas także w przekonaniu, że idziemy słuszną drogą. Coraz mniejsza liczba organizatorów się zmienia, a coraz więcej instytucji chce iść z nami dalej i pewniej.

Szóstej edycji dopisała nadspodziewanie dobra pogoda w postaci ponadtrzydziestostopniowego upału, który nie bardzo pomagał ani organizatorom, ani odwiedzającym. Myślę jednak, że zarówno jedni jak, i drudzy dobrze wy- 